Available online at: http://ejournal.unpas.ac.id/index.php/litigasi

Litigasi, Vol. 17(2), 2016, 3377 - 3426

DOI: http://dx.doi.org/10.23969/litigasi.v17i2.139

\title{
INTERAKSI HUKUM NEGARA DAN HUKUM ADAT DALAM PENANGGULANGAN INDONESIA \\ TRAWL \\ DI
}

\section{SULAIMAN}

Fakultas Hukum Universitas Syiah Kuala, Jl. Putroe Phang No. 1 Kopelma Darussalam, Syiah Kuala, Kota Banda Aceh, Aceh 23111, e-mail: st_aceh@yahoo.co.id.

\begin{abstract}
ABSTRAK
Trawl yang digunakan oleh sebagian nelayan lokal di Indonesia, di samping melanggar hukum negara dan hukum lokal, juga menimbulkan dampak serius lainnya terhadap fungsi lingkungan. Makalah ini ingin menjawab tiga permasalahan utama: apa yang menyebabkan masyarakat lokal menggunakan trawl? Langkah apa saja yang dilakukan pemerintah dalam menanggulangi trawl? Bagaimana interaksi ideal hukum negara dan hukum lokal dalam penanggulangan trawl? Makalah ini menyimpulkan bahwa proses pemakaian trawl yang disadari dampaknya, tidak lepas dari proses modernisasi, trawl tersebut dirasionalkan akan mempercepat peningkatan ekonomi nelayan. Pemerintah Kabupaten sudah melakukan langkah untuk melahirkan kebijakan responsif dalam rangka mengendalikan dampak yang muncul, namun kebijakan itu lahir lebih karena tekanan masyarakat sendiri. Interaksi yang ideal adalah keterbukaan hukum negara dan hukum lokal untuk saling berhubungan dalam konteks melengkapi satu sama lain.
\end{abstract}

Kata Kunci: Interaksi hukum, hukum adat, hukum negara, trawl.

\begin{abstract}
Trawling is used by most of the local fishermen in Indonesia, in addition to unlawful state and local laws, as well as more serious impact on the function of the environment. This paper would like to address three main issues: what make local communities using trawling? What steps should the government do in combating trawling? How the ideal interaction of state law and local law in the response to trawling? The paper concludes that the use of trawl conscious process impact, can not be separated from the process of modernization, the trawl rationalized will accelerate economic improvement fishermen. District Government is already taking action to give birth responsive policy in order to control the impact of emerging, but the policy was born due to the community itself. The ideal interaction openness state law and local to interact in the context of complement each other.
\end{abstract}

Keywords: Interaction law, customary law, state law, trawling.

Copyright @ 2016 , LITIGASI, p-ISSN: 0853-7100; e-ISSN: 2442-2274 
Available online at: http://ejournal.unpas.ac.id/index.php/litigasi

Litigasi, Vol. 17(2), 2016, 1377 - 3426

DOI: http://dx.doi.org/10.23969/litigasi.v17i2.139

\section{PENDAHULUAN}

Penggunaan pukat trawl dan modifikasinya dalam bentuk minitrawl olehn elayan lokal di sebagian wilayah pesisir Indonesia, tidak saja melanggar hukum negara. Penggunaan alat tangkap tersebut juga melanggar hukum adat, yang secara sosiologis masih ditemui dalam masyarakat.

Kajian Purbayanto (Solihin, 2010 : 80-81) menyebutkan, bahwa trawl dan minitrawl dengan berbagai modifikasinya tersebar hampir di seluruh perairan Indonesia, besar atau kecil, legal maupun ilegal, mulai dari Selat Malaka, Selat Karimata, Laut Jawa, Selat Makasar, Laut Flores, Selat Tiworo, Laut Seram, Teluk Tomini, Laut Sulawesi, Samudera Fasifik, Teluk Bintuni, Arafura, Aru, Laut Banda, hingga Samudera Hindia, bertebar pukat trawl, dengan nama yang berbeda-beda.

Menurut Surat Keputusan Menteri Pertanian No. 503/KPTS/UM/7/1980 tentang Jalur Penangkapan Ikan, yang dimaksud trawl adalah jenis jaring yang berbentuk kantong yang ditarik sebuah kapal bermotor dan menggunakan sebuah alat pembuka mulut jaring (gawang) atau sepasang alat pembuka dan jaring yang ditarik oleh dua kapal bermotor. Jenis jaring trawl dikenal dengan nama pukat harimau, pukat tarik, tangkul tarik, jaring tarik, jaring tarik ikan, pukat Apollo, serta pukat langgai.

Sementara menurut Firdaus (2010:22-28), minitrawl merupakan alat tangkap ikan jenis jaring berbentuk kantong yang dilengkapi sepasang papan pembuka mulut jaring. Target penangkapannya adalah udang dan ikan dasar (demersal). Pengoperasian ditarik oleh satu kapal motor. 
Munculnya modifikasi trawl, dipengaruhi oleh antara lain hukum negara yang memberi celah penggunaan trawl. Dalam hal ini, penggunaan istilah "hukum negara" untuk menegaskan konsep hukum positif yang berupa peraturan perundang-undangan yang dikeluarkan oleh negara. Apeldoorn (1981:304), memaknai tidak saja meliputi hukum (administratif), melainkan juga menunjukkan orang-orang yang memegang kekuasaan pemerintahan dan batas-batas kekuasaannya.

Pada dasarnya semua alat yang dipakai dalam pemanfaatan sumberdaya perikanan digolongkan sebagai alat tangkap. Pengaturan hukum negara mengenai alat tangkap, ditemui dalam Pasal 7 ayat (1) huruf f Undang-Undang No. 45 Tahun 2009 tentang Perubahan Undang-Undang No. 31 Tahun 2004 tentang Perikanan menentukan bahwa pengaturan alat tangkap diatur dengan Keputusan Menteri Kelautan dan Perikanan. Peraturan tersebut direalisasikan dengan Keputusan Menteri Kelautan dan Perikanan No. Kep.06/MEN/2010 tentang Alat Penangkapan Ikan di Wilayah Pengelolaan Perikanan Negara Republik Indonesia.

Dalam peraturan tersebut, ditetapkan adanya 10 kelompok alat penangkap ikan yang boleh digunakan di Wilayah Pengelolaan Perikanan Negara Republik Indonesia, yakni: (1) jaring lingkar (surrounding nets); (2) pukat tarik (seine nets); (3) pukat hela (trawls); (4) penggaruk (dredges); (5) jaring angkat (lift nets); (6) alat yang dijatuhkan (falling gears); (7) jaring insang (gillnets and entangling nets); (8) perangkap (traps); (9) pancing (hooks and lines); (10) alat penjepit dan melukai (grappling and wounding). 
Dengan pengaturan tersebut, tampak bahwa jenis alat tangkap yang dapat digolongkan ke dalam trawl, diperbolehkan dipergunakan walau dalam implementasinya ditentukan pada daerah tertentu saja. Pengaturan tersebut menimbulkan perdebatan, terutama dengan adanya Keputusan Presiden Nomor 39 Tahun 1980 tentang Larangan Trawl. Pada waktu itu, pemerintah juga mengatur jalur penangkapan ikan melalui Keputusan Menteri Pertanian No. 694 Tahun 1980, dengan ketentuan larangan bagi semua usaha perikanan menggunakantrawl dan larangan melakukan pengangkutan ikan dengan kapal perikanan yang menggunakan trawl.

Corak pengaturan demikian, ditambah dengan adanya ketentuan pelaksana yang memberi ruang penggunaan pukat trawl dalam Undang-Undang (seanjutnya disingkat UU) Perikanan sekarang ini, paling tidak berimplikasi kepada penggunaan trawl makin merajalela.

Hal lainnya adalah kebijakan khusus Pemerintah yang pernah mengizinkan trawl khususnya di perairan barat Indonesia. Bagian dari masing-masing kebijakan, dapat dilihat juga melalui Surat Keputusan Menteri Pertanian Nomor: 508/Kpts/PL.810/7/96 tentang Pengadaan dan Penghapusan Sistem Sewa Kapal-Kapal Berbendera Asing. Pengaturan ini, sebenarnya secara implisit memberi ruang untuk mengimpor untuk menggunakan trawl dengan kategori tertentu. Di samping itu, Keputusan Menteri Pertanian Nomor: 770/Kpts/IK.120/10/96 tentang Pengunaan Pukat Ikan Di ZEEI Samudera Hindia Perairan Barat Sumatera.

Peraturan tersebut, menegaskan adanya "restu" dari hukum negara untuk penggunaan trawl, sementara pada sisi lain, trawl berdampak serius dalam lingkup 
lainnya, yakni ekologis, kultural, dan konflik sosial. Secara ekologis, trawl menghancurkan proses regenerasi ikan, yang memiliki implikasi sangat buruk bagi ekosistem. Benih ikan yang masih kecil turut terjaring tetapi tidak dikehendaki, maupun ikan berukuran kecil yang tidak bisa dimanfaatkan (baik untuk dijual maupun dikonsumsi), pada akhirnya dibuang begitu saja (Abdullah et.,al., 2012 : 37-46).

Secara kultural, perilaku semacam ini mengingkari konsep pemulihan fungsi lingkungan hidup pesisir dan kelautan menurut hukum lokal yang masih hidup dan berkembang. Dalam hal ini, yang dimaksud dengan hukum lokal adalah integrasi hukumhukum yang sedang berlaku pada tingkat empirik di lapisan bawah dari sistem sosial suatu masyarakat (Rato, 2004 : 245). Ada berbagai istilah yang digunakan untuk hukum lokal, yakni hukum rakyat, hukum adat, atau hukum lain yang diversuskan dengan hukum negara (Fidiyani, 2009 : 353; Simarmata, 2005 : 3; Benda-Beckmann, $2005: 24)$.

Hukum adat yang terkait dengan kelautan dan perikanan, khususnya di Aceh, dikenal dengan nama hukum adat laut. Corak hukum ini terkait dengan upaya untuk memelihara dan mengawasi setiap usaha penangkapan ikan. Di samping itu, terkait dengan kelautan dan perikanan, adalah upaya menjaga dan mengawasi agar pohon di tepi pantai terjaga, karena hal tersebut terkait dengan ekosistem (Sulaiman, 2010: 154).

Hukum adat laut juga memiliki sistem aturan, dimana salah satu isi di dalamnya adalah adat pemeliharaan lingkungan. Dalam aturan ini, setiap orang dilarang melakukan: (a) pemboman, peracunan, pembiusan, penglistrikan, pengambilan terumbu karang, dan 
bahan-bahan lainnya yang dapat merusak lingkungan hidup dan biota lainnya; (b) menebang / merusak pohon-pohon kayu di pesisir pantai laut seperti pohon arun / cemara, pandan, ketapang, bakau dan pohon lainnya yang hidup di pantai; (c) menangkap ikan / biota laut lainnya yang dilindungi (lumba-lumba, penyu, dan lain sebagainya) (Sulaiman, 2010: 154).

Hukum adat laut dilaksanakan oleh Lembaga Panglima Laut, dimana dalam melestarikan adat, lembagai ini bertanggung jawab: (a) memelihara dan mengawasi ketentuan-ketentuan hukum adat laut dan adat laot; (b) mengkoordinasikan dan mengawasi setiap usaha penangkapan ikan laut; (c) menyelesaikan perselisihan/sengketa yang terjadi diantara sesama nelayan atau kelompoknya; (d) mengurus dan menyelenggarakan upacara adat laot; (e) menjaga dan mengawasi agar pohon-pohon di tepi sungai tidak ditebang, karena ikan akan menjauh sampai tengah laut; (f) penghubung antara nelayan dan pemerintah dalam melaksanakan program pembangunan perikanan; (g) meningkatkan usaha yang dapat meningkatkan taraf hidup masyarakat nelayan; (h) mengatur jadwal acara-acara ritual yang berhubungan dengn masyarakat nelyan, misalnya kenduri laut (Sulaiman, 2010: 154).

Dengan demikian, hukum adat laot tersebut sebagai wujud hukum lokal, melarang penggunaan segala jenis alat tangkap yang destruktif terhadap fungsi lingkungan hidup termasuk trawl. Pengingkaran tersebut dianggap tidak hanya mengganggu hubungan manusia dengan lingkungan, akan tetapi juga hubungan manusia dengan Pencipta (Sulaiman, 2011 : 298). Secara kultural diingatkan, sumberdaya perikanan harus 
dimanfaatkan seoptimal mungkin, yang penyia-nyiaan terhadapnya diyakini berpengaruh terhadap daya rasa syukur atas rezeki dari Pencipta (Sulaiman, 2009 : 35).

Dampak serius lainnya adalah konflik sosial, yang lahir karena adanya kesadaran kumulatif dari sebagian nelayan kecil untuk berupaya melawan segala bentuk penggunaan alat tangkap destruktif termasuk trawl. Berbagai konflik di beberapa wilayah pesisir, memperlihatkan adanya nelayan yang menginginkan adanya penertiban terhadap trawl yang berimplikasi bagi kehidupan mereka. Konflik fisik yang terjadi mulai dari ujung Sumatera, Jawa, hingga Kalimantan, hingga menimbulkan korban yang tidak kecil.

Konflik terjadi, bagi nelayan anti trawlkarena hukum negara hampir tidak menjalankan fungsinya. Malah secara implisit, berimplikasi kepada pengabaian hukum lokal yang dijunjung oleh mereka.Relasi demikian tidak sehat, namun dimungkinkan terjadi. Menurut Hooker, hukum negara dan hukum lokal memiliki tiga corak interaksi: Pertama, hukum negara secara politik lebih berkuasa karena memiliki kemampuan menghancurkan hukum lokal. Kedua, terdapat pertentangan kewajiban, aturan yang dibuat oleh sistem hukum negara secara mutlak berlaku dan sistem hukum lokal dapat tetap berlaku selama diizinkan oleh sistem hukum negara dan dilaksanakan sesuai dengan bentuk yang dipersyaratkan oleh negara. Ketiga, setiap penggambaran ataupun pengkajian hukum adat yang dilakukan harus mengikuti klasifikasi hukum yang dianut oleh sistem hukum negara (Griffith, $2005: 81$ ).

Menurut Goodman, ada empat tipe interaksi sosial hukum negara dan hukum lokal yang selama ini dikenal, yakni: (1) interaksi berupa benturan keras, dan dalam hal ini hukum negara yang selalu menjadi pemenang; (2) hukum negara dan hukum lokal 
sama-sama menghindar berbentur; (3) hukum negara dan hukum lokal sama-sama menyesuaikan; (4) hukum negara dan hukum lokal sama-sama saling mendominasi (Fidiyani, 2009 : 353).

Berdasarkan penjelasan tersebut, memberikan gambaran dampak dahsyat dari penggunaan trawl. Dengan demikian, adanya ketentuan pelarangan trawl merupakan langkah tepat dalam menjawab dampak yang ditimbulkan. Masalahnya adalah ketentuan sendiri memberikan ruang bagi penggunaan alat tangkap tersebut di beberapa daerah. Masalah lainnya adalah mengapa hingga sekarang dalam masyarakat masih ditemui adanya trawldalam bentuk minitrawl? Bahkan alat tersebut dipergunakan oleh nelayan lokal sendiri. Apakah ini yang kemudian menjadi alasan sulitnya trawl tersebut ditertibkan oleh pemerintah?

Pertanyaan-pertanyaan semacam itu mencuat ketika mengukur dampak yang ditimbulkan. Apalagi dikaitkan dengan kepentingan pemerintah yang seharusnya menjadikan dampak-dampak yang muncul tersebut sebagai bagian dari penghambat pembangunan dalam arti luas.

Suasana tersebut tampak problematik. Di satu pihak, hukum negara memberi ruang untuk menggunakan alat tangkap jenis minitrawl. Alat tangkap jenis ini mengakibatkan kerusakan lingkungan. Hal lain yang diatur dalam hukum negara adalah mengakui dan menghormati adanya hukum adat yang mengatur bidang perikanan. Di pihak lain, hukum negara mengatur bahwa pemanfaatan sumberdaya perikanan harus memperhatikan keberlanjutan lingkungan. Hukum adat juga dengan tegas menolak menggunakan alat tangkap yang merusak lingkungan. 
Dari suasana problematik tersebut, disusun pertanyaan permasalahan sebagai berikut: (1) Apa yang menyebabkan masyarakat lokal menggunakan minitrawl? Mengapa terjadi ketidakcocokan antara hukum negara dan hukum adat dalam pengaturan alat tangkap? (2) Bagaimana tindakan pemerintah dalam menghadapi ketidakcocokan antara hukum negara dan hukum adat dalam pengaturan mengenai penggunaan alat tangkap minitrawl? (3) Bagaimana interaksi ideal hukum negara dan hukum adat dalam penanggulangan penggunaan minitrawl dalam masyarakat?

\section{PEMBAHASAN}

\section{A.Penggunaan Trawl di Indonesia}

Sejak tahun 1969 pukat trawl sudah digunakan di Indonesia. Trawl berkembang pesat tahun 1970-an, karena dua kondisi, yakni: Pertama, tingginya permintaan dunia untuk udang. Kedua, berkembangnya perusahaan perikanan udang, baik dalam bentuk Penaman Modal Asing (PMA) maupun Penanaman Modal dalam Negeri (PMDN) (Barani, 2003 : 5). Kondisi tersebut sekaligus menjadi alasan proses modernisasi alat tangkap perikanan (Wijayanto, $2006: 6$ ).

Pertengahan 1980-an modernisasi perikanan mencapai puncak perkembangannya. Kompleksitas masalah pun mulai bermunculan, terutama yang terkait dengan keadilan lingkungan (Poerwanti, 2008 : 195).

Seyogianya, modernisasi harus dilakukan dengan hati-hati (Marlina dan Riza, 2013 : 5-6). Pukat trawl mewakili harapan wajah modernisasi, dengan nama yang beragam di berbagai daerah, seperti pukat harimau, pukat hela, pukat minitrawl, dan 
sebagainya. Terdapat ragam nama memunculkan kesan bahwa alat tangkap tersebut sah digunakan (Tribawono, 2013 : 119). Dalam Statistik Perikanan Tangkap, trawl dimasukkan dalam beberapa kategori, yakni pukat tarik udang ganda, pukat tarik udang tunggal, pukat tarik berbingkai, dan pukat tarik ikan (Marwoto, 2013 : xxi).

Kenyataan di negara kita yang menyadari adanya hukum lokal di samping hukum negara, maka modernisasi bisa menjadi masalah, terutama munculnya model formasi sosial baru yang lebih bergantung pada modal pasar ketimbang modal sosial (Poerwanti, 2008 : 195). Modernisasi cenderung merenggut manusia dari rasa tenteram kosmologis yang diperoleh melalui pandangan agama dan tradisional (Rato, 2009 : 15).

Kesadaran ini sepertinya ada. Buktinya ketika trawl muncul, pengaturan jalur penangkapan ikan juga dilakukan, yakni SK Mentan No. 607/Kpts/Um/9/1976 tentang Jalur Penangkapan Ikan. Pengaturan tersebut dilakukan untuk melindungi pelestarian dan daerah perairan dari kegiatan penangkaran yang menggunakan jenis peralatan tertentu, serta melindungi nelayan kecil yang tingkat kemampuan operasional unit penangkapannya masih terbatas. Hal tersebut dapat dilihat dari pembagian jalur penangkapan, dimana pada jalur I (perairan pantai selebar 3 mil laut) pengaturannya sangat ketat. Secara implisit, keberadaan pukat trawl dari awal disadari akan membawa dampak, terutama menghancurkan proses regenerasi stok ikan karena ikan yang tertangkap diantaranya adalah benih. Dampak lainnya adalah kelestarian ikan demersal (ikan yang berada pada posisi paling dasar). Penggunaan trawl juga menimbulkan konflik antara nelayan tradisional dan nelayan trawl (Barani, 2003 : 6). Pukat trawl dianggap mengganggu keseimbangan dan berakibat pada terganggunya pendapatan nelayan 
tradisional, padahal mereka menggunakan alat tangkap ramah lingkungan dan dengan jangkauan wilayah yang sangat terbatas (Syaref, 2003 : 66-67).

Menyadari dampak, Presiden mengeluarkan Keppres Pelarangan Trawl, disusulKepmentan No. 694 Tahun 1980. Pada perjalanannya, muncul usaha untuk memodifikasi trawl, agar dapat dipergunakan dan tidak melanggar hukum, dengan nama minitrawl. Namun ia tetap mengancam ikan demersal dan memunculkan konflik sesama nelayan. Mengantisipasi kondisi tersebut, dikeluarkan Keputusan Direktorat Jenderal Perikanan Nomor IK. 340/DJ.10106/97 tentang Petunjuk Pelaksanaan Keputusan Menteri Pertanian Nomor 694 Tahun 1980. Keputusan ini mempertegas spesifikasi trawl yang tidak boleh dipergunakan. Keputusan tersebut membingungkan dan bersifat multi tafsir, terutama dikaitkan penegasan suatu alat tangkap termasuk kategori trawl atau tidak.

Dalam perjalanannya, larangan trawl ternyata bukan harga mati. Keppres No. 85 Tahun 1982 tentang Penggunaan Pukat Udang, memboleh pukat yang menyerupai trawl, khusus beroperasi di Wilayah Perairan Kei, Tanimbar, Aru, Irian Jaya, dan Laut Arafura. Kepprres sepertinya menjadi jalan tengah, di mana tuntutan melarang dan menggunakan trawl masing-masing ada dasar hukumnya. bedanya, yang larangan trawl terkait dengan upaya pelestarian lingkungan dan menghindari konflik sosial, sedangkan pukat udang dalam rangka mengimbangi gelora permintaan udang dunia yang kabarnya waktu itu beranjak naik.

Berbagai perkembangan membuat Permentan (694/1980) juga diubah dengan Kepmen No. 392 Tahun 1999, yang mengatur keberadaan tiga jalur, yakni: 
1) dari pantai hingga 6 mil ke arah laut (Jalur I);

Jalur I khusus untuk kapal tanpa motor atau bermotor dengan ukuran maksimal 5 GT.

2) 6-12 mil (Jalur II);

Jalur Penangkapan II untuk kapal bermotor dengan ukuran maksimal 60 GT.

3) dan 12 mil hingga batas terluar ZEEI (Jalur III).

Jalur III diperuntukkan bagi kapal bermotor dengan ukuran lebih besar dari 60 GT.

Semangat pengaturan jalur penangkapan ikan, pada dasarnya adalah bukan hanya ingin menyelamatkan nelayan tradisional, akan tetapi juga ingin menyelamatkan ekosistem laut. Sebagai bagian dari ketentuan pelaksana larangan trawl, jalur penangkapan mewakili yang disebut Bedner sebagai konsep konservasi namun penggunaan sumberdaya dibolehkan dengan mekanisme izin tertentu (Bedner, 2007 : 91).

Tahun 2008, Menteri mengeluarkan Permen No. 6 Tahun 2008, mengatur kegiatan penangkapan ikan di perairan Kalimantan Timur bagian utara dapat dilakukan dengan menggunakan kapal pukat hela, dengan ketentuan:

1) Jalur I (perairan 1-4 mil) hanya diperbolehkan bagi kapal pukat hela ukuran sampai dengan 5 GT;

2) Jalur II (perairan 4-12 mil) hanya diperbolehkan bagi kapal pukat hela ukuran sampai dengan 30 GT. Kapal Jalur I boleh beroperasi di Jalur II, tetapi kapal Jalur II tidak boleh di Jalur I.

Copyright @ 2016, LITIGASI, p-ISSN: 0853-7100; e-ISSN: 2442-2274 
Jaring Hela adalah semua jenis alat penangkapan ikan berbentuk jaring berkantong, berbadan dan bersayap yang dilengkapi pembuka jaring yang dioperasikan dengan cara ditarik/dihela menggunakan satu kapal yang bergerak [SNI 01-7232-2006 dan SNI 7277.5:2008]), yang dimaksudkan untuk membangkitkan ekonomi (berdasarkan usulan Bupati Bulungan, Berau, Malinau, Nunukan dan Walikota Tarakan; Pemerintah Provinsi Kalimantan Timur, dan HNSI Kalimantan Timur). Pukat ini juga berpotensi merusak kelestarian dan menebar konflik (Tribawono, 2013).

Di samping itu, Surat Keputusan Menteri Pertanian Nomor: 508/Kpts/PL.810/7/96 tentang Pengadaan dan Penghapusan Sistem Sewa Kapal-Kapal Berbendera Asing, secara implisit memberi ruang untuk mengimpor trawl dengan kategori tertentu. Keputusan Menteri Pertanian Nomor : 770/Kpts/IK.120/10/96 tentang Pengunaan Pukat Ikan Di ZEEI Samudera Hindia Perairan Barat Sumatera.Terakhir Keputusan Menteri Kelautan dan Perikanan No. Kep.06/MEN/2010 yang menegaskan 10 kelompok alat tangkap yang boleh dipergunakan di Indonesia, termasuk di antaranya pukat hela dan pukat tarik.

Kenyataan tersebut seperti sebuah kemunafikan, di satu sisi terlarang, di sisi lain jadi alat tangkap "kesayangan". Menarik lagi, beberapa daerah memodifikasinya menjadi lebih kecil (mini trawl), sedangkan ketidakberdayaan Pemerintah menanggulangi trawl, dijawab dengan penerbitan izin trawl pada wilayah tertentu (Solihin, 2010 : 76-79). Sekarang ini trawl tersebar hampir di seluruh perairan Indonesia, besar atau kecil, legal maupun ilegal, mulai dari Selat Malaka, Selat Karimata, Laut Jawa, Selat Makasar, Laut Flores, Selat Tiworo, Laut Seram, Teluk Tomini, Laut Sulawesi, Samudera Fasifik, Teluk 
Bintuni, Arafura, Aru, Laut Banda, hingga hingga Samudera Hindia, bertebar pukat trawl, dengan nama yang berbeda-beda (Purbayanto, 2007 : 8; Solihin, 2010 : 8081).

Berbagai perkembangan pengaturan tersebut, pada dasarnya menggambarkan adanya suasana tarik-menarik antara kepentingan hukum, ekonomi, sosial-budaya, dan bahkan ekologi. Sebuah pengaturan merupakan proses perjumpaan berbagai kepentingan.

Dalam corak yang demikian, menjadi relevan kita melihat konsep pembangunan hukum Indonesia yang sesungguhnya berporos pada kebijakan kodifikasi dan unifikasi. Dalam banyak hal, pembangunan hukum turut dipengaruhi oleh berbagai kepentingan, baik dalam maupun luar negeri, atau bahkan kepentingan-kepentingan yang sebenarnya di luar kepentingan hukum itu sendiri.

Pengaturan modernisasi alat tangkap menjadi contoh bagaimana hukum negara mendominasi hukum lokal dalam hal penggunaan alat tangkap yang ujungnya berimplikasi kepada lingkungan.Pengaturan dalam hukum lokal, yakni hukum adat laot, semua alat tangkap yang berpotensi merusak lingkungan, terlarang untuk digunakan. Menggunakan trawl pengaturannya dalam hukum adat termasuk dalam aturan yang mengatur lingkungan.

Pengaturan dalam penggunaan alat tangkap terkait dengan konsep keberlanjutan, yang sudah disadari masyarakat lokal. Terdapat empat kategori pengaturan terkait dengan trawl, terkait dengan keberlanjutan ini.Pertama, penggunaan ukuran jaring terkait yang tidak boleh kurang dari ukuran tertentu. Dalam praktek, ukuran jaring mini trawl di 
bawah $1 \mathrm{~cm}$. Ukuran tersebut dipandang membahayakan sumber daya ikan bagi masyarakat lokal, yang memiliki corak hidup "cok ube sep, pajoh ube memada, publoe ube gaseh, tuka uber kada" (ambil menurut perlu, makan menurut kebutuhan, jual menurut rezeki, menukar menurut kadar). Dengan menggunakan jaring ukuran di bawah $1 \mathrm{~cm}$, dipandang akan berimplikasi tidak hanya bagi menipisnya sumber daya, melainkan juga meningkatnya keserakahan.

Hal lain yang terkandung dengan larangan tersebut adalah sesuai dengan tujuan pelestarian sumber daya perikanan. Jaring yang ukurannya sangat kecil akan mengangkat benih ikan yang tidak bisa dikonsumsi dan hancurnya biota laut dan terumbu karang sebagai rumah ikan.

Kedua, waktu penangkapanikan tidak boleh melanggar ketentuan waktu melaut menurut adat. Dalam hukum adat laot dikenal ada larangan melaut pada waktu tertentu. Hal tersebut harus dipatuhi mengingat secara adat ada filosofi tersendiri dalam pelaksanaan larangan atau pantangan tersebut. Dalam adat Aceh disebut, "uroe meu cahya, malam meu purnama, sigo-go meu harga, sidum-dum cok hasa" (hari bercahaya, malam berpurnama, sekali-kali waktu berharga, untuk kemudian banyak memungut hasilnya).

Ketiga, larangan menangkap jenis ikan tertentu, yang tidak bisa dipisahkan dalam jaring tertentu. Dengan ukuran jaring mini trawl yang sangat kecil, pemilahan jenis ikan untuk tujuan konservasi sumber daya tidak mungkin dilakukan. Ketentuan adat menyebutkan, "eungkot kareng wate duha, eungkot karang wate sinja, eungkot ubeut 
bek peutimpa, eungkot meuharga bek seuguna" (ikan teri waktu pagi, ikan karang saat senja, ikan kecil harus dijaga, ikan tertentu jangan disia-siakan).

Keempat, pengaturan penggunaan alat tangkap tidak bisa dilepaskan dari kegiatan konservasi daerah yang selama ini sedang digalakkan. Penyebutan kawasan konservasi daerah pada dasarnya untuk membedakan dengan konsep konservasi pada umumnya. Konservasi daerah diatur menurut keadaan daerah masing-masing. Dalam hal ini, konservasi daerah di Aceh salah satu terkait dengan teknik penangkapan ikan dari jaring tertentu. Semangat konservasi demikian berbasis pada ketentuan adat yang mengatur, "jak meu laot di lua musem barat, jak meu rawat wate musem asa” (melaut di luar musim angin barat, sedangkan merawat dan melestarikan lingkungan harus dilakukan walau musim melaut telah tiba).

Secara substansi, hukum adat laut yang mengatur penggunaan jaring yang ramah lingkungan berhubungan langsung dengan pemanfaatan dan pengelolaan sumber daya perikanan yang berkelanjutan. Pola pengelolaan dikaitkan dengan perilaku usaha penangkapan ikan di laut yang harus dilakukan sesuai dengan hukum adat laut. Lembaga hukum adat laut (Panglima Laut) melaksanakan tugas mengkoordinasikan dan mengawasi setiap usaha penangkapan ikan di laut tersebut.

Namun demikian, pola tersebut hanya dapat dilaksanakan dalam wilayah hukum adat laot, yang dinamakan dengan leun pukat. Jarak kawasan ini dapat disebut sebagai kawasan otonom hukum adat laot.

Sementara untuk wilayah yang di luar leun pukat, lembaga hukum adat laut dan masyarakat memiliki tanggung jawab yang lebih luas dalam melestarikan adat dan 
menjembatani kepentingan dengan pemerintah. Secara khusus, hukum adat laot menentukan nelayan atau masyarakat hukum adat laot yang mencurigai atau menemukan kapal asing yang memasuki wilayah perairan Indonesia atau kapal Indonesia yang menggunakan alat tangkap yang tidak ramah lingkungan, segera dilapor kepada lembaga hukum adat laot. Laporan tersebut kemudian diteruskan kepada pihak berwajib (Abdullah dkk, 2006: 79).

Ketentuan lainnya adalah jika seorang nelayan atau masyarakat hukum adat laot melihat adanya kapal yang melanggar atau melakukan kegiatan yang merusak lingkungan, maka segera dilaporkan kepada lembaga hukum adat laot atau pihak berwajib (Abdullah dkk, 2006: 80). Tanggung jawab kolektif semacam ini, dimaksudkan sebagai upaya mewujudkan keadilan, kesejahteraan, dan keberlanjutan sumber daya perikanan bagi masyarakat sendiri. Terdapat tujuan hakiki yakni mencapai tujuan kesejahteraan dalam pembangunan.

Secara filosofis, hukum adat sebagai hukum yang hidup (living law) dikonsepsikan sebagai suatu sistem hukum yang terbentuk dan berasal dari pengalaman empiris masyarakat masa lalu, yang dianggap adil dan patut dan telah mendapat letigimasi dari penguasa adat sehingga mengikat dan wajib dipatuhi (Soemadiningrat, 2002: 27).

Di samping itu, untuk hukum adat laot, tersedia sistem sanksi, dengan tujuan hukum utama dari sistem sanksi ini adalah kemanfaatan. Sanksi yang dikenakan bagi pelanggar hanya dua, yakni: Pertama, penyiataan hasil tangkapan yang akan dipergunakan untuk agama dan sosial. Kedua, bila pelaku nelayan lokal dilarang melaut 
mulai tiga hingga tujuh hari, tetapi untuk nelayan luar diserahkan kepada pihak berwajib (Abdullah dkk, 2006: 80).

Sanksi yang tersedia dalam hukum adat laot, pada prinsipnya bukan untuk menghukum, melainkan untuk keseimbangan keadaan sosial yang telah terlanggar. Keseimbangan sesuai dengan yang dimaksudkan Mohammad Koesnoe sebagai keberlakuan hukum adat berasas rukun, patut, dan laras. Asas ini oleh Shidarta disebut sebagai cermin aksiologis dari hukum adat di Indonesia (Shidarta, 2013: 27).

Dalam konteks Aceh, untuk pengaturan hal tertentu, hukum adat laut memiliki keberagaman antara satu kawasan dengan kawasan lain. Namun khusus untuk penggunaan alat tangkap tidak ramah, aturan hukum adatnya sama. Perbedaan misalnya hanya pada ada atau tidaknya sanksi tambahan. Contohnya pelaku dari nelayan lokal, akan mendapat cibiran secara sosial selain yang dua sanksi di atas (Abdullah dkk, 2006: $80)$.

Dengan kenyataan ini, hukum negara dan hukum adat bisa saling bersaing. Gambaran tersebut, memperliharkan realitas sosial pada dasarnya dapat dipahami dengan menampilkannya bersama dengan kekuatan-kekuatan yang bekerjanya hukum di balik realitas tersebut.

Secara lebih dalam, ia tidak bisa berdiri sendiri. Ada sejumlah subsistem yang terkonfigurasi sedemikian rupa. Talcott Parsons menyebutkan, tiap subsistem dalam sistem, selain terpasang dalam posisi tertentu, juga mengemban tugas tertentu. Potret yang kesemuanya itu disingkat dengan AGIL, yakni adaptation, goalattainment, integration, dan latency.

Copyright $\odot$ 2016, LITIGASI, p-ISSN: 0853-7100; e-ISSN: 2442-2274 
Available online at: http://ejournal.unpas.ac.id/index.php/litigasi

Litigasi, Vol. 17(2), 2016, 1377 - 3426

DOI: http://dx.doi.org/10.23969/litigasi.v17i2.139

Konfigurasi A GIL dapat dijelaskan sebagai berikut:

1) Adaptation, sebuah sistem harus menanggulangi situasi eksternal yang gawat. Sistem harus menyesuaikan diri dengan lingkungan dan menyesuaikan diri dengan kebutuhannya;

2) Goal attainment, sebuah sistem harus mendefinisikan dan mencapai tujuan utamanya;

3) Integration, sebuah sistem harus mengatur antar hubungan bagian-bagian yang menjadi komponennya. Sistem juga harus mengelola antar hubungan ketiga fungsi penting lainnya;

4) Latency, sebuah sistem harus memperlengkapi, memelihara dan memperbaiki, baik motivasi individual maupun pola-pola kultural yang menciptakan dan menopang motivasi (Ritzer dan Goodman, 2004 : 121).

Dengan skema AGIL, klarifikasi fungsi sistem adalah sebagai pemeliharaan pola (sebagai alat internal), integrasi (sebagai hasil internal), pencapaian tujuan (sebagai hasil eksternal), dan adaptasi (alat eksternal).

Menurut Parsons, persyaratan kunci terpeliharanya integrasi pola nilai dan norma ke dalam sistem adalah dengan sosialisasi dan internalisasi. Proses sosialisasi yang sukses, nilai dan norma sistem sosial itu akan diinternalkan.

Dalam relasi struktural dan fungsional, dapat diketahui bahwa adaptasi merupakan kebutuhan fungsional berupa kemampuan subsistem menjamin kebutuhannya dari lingkungannya, dan mendistribusikan sumber-sumber ke seluruh sistem dalam masyarakat. Fungsi itu diperankan oleh subsistem ekonomi. Sehingga melalui motivasi 
ekonomi, sumberdaya diubah menjadi fasilitas yang dapat digunakan untuk berbagai tujuan (Rahardjo, $2006: 132-136$ ).

Di samping itu, masuknya subsistem politik berkaitan dengan fungsi politik untuk mengejar tujuan. Dalam hal ini masyarakat senantiasa berusaha untuk mencapai berbagai tujuan yang dianggap baik. Dalam proses tersebut, kemudian ada subsistem sosial yang memerankan dalam proses pengintegrasian.

Dengan kondisi di atas, penggunaan trawl yang awalnya disebabkan adanya kepentingan tertentu, menyebabkan timbulnya implikasi negatif yang secara hukum dan sosial harus ditanggulangi, maka langkah pengintegrasian adalah langkah yang dilakukan walau kenyataannya terjadi tolak-talik antara norma negara dengan norma dalam masyarakat.

Pada tahap ini, konsep modernisasi melalui hukum negara sebenarnya sedang diuji, sekaligus memperlihatkan dominasinya terhadap hukum lokal yang hidup dalam masyarakat. Pada tataran lebih tinggi, modernisasi sebagai teori tidak bisa dilepaskan dari konsep pembangunan dengan beranjak pada perubahan sosial, yang tersembunyi berbagai kepentingan. Reinhard Bendix menunjuk tipe perubahan sosial yang berasal dari Revoluasi Industri dan Revolusi Politik abad ke-18 (Samekto, 2008 : 69-72).

Modernisasi ini pada dasarnya sedang berlangsung manipulasi kekuasaan melalui hukum demi kepentingannya. Dengan menggunakaan anatomi Nonet dan Selznick, maka pada tahap ini yang berlangsung sebenarnya adalah hukum represif. Makna hukum represif di sini adalah hukum yang tidak diabdikan untuk kepentingan masyarakat agar mengarah kepada yang lebih baik (Samekto, 2012 : 99). 
Dengan demikian, posisi hukum represif tidak semata-mata sebagai hukum yang memperlakukan masyarakat secara semena-mena. Dalam hal ini, hukum represif termasuk juga dalam hal mengabaikan berbagai kepentingan kesejahteraan yang holisitik dari masyarakat (Nonet dan Selznick, 2008 : 18-32).

Atas dasar itulah, maka melakukan hal apapun, semisal modernisasi alat tangkap yang berdampak kerusakan lingkungan, tidak boleh hanya semata-mata diukur dengan pengaturan hukum negara yang formal. Pengaturan yang mengganggu hingga titik kosmologi, bisa menyebabkan mengganggu hukum dalam masyarakat. Makanya penaturan yang semacam itu harus dilakukan hati-hati. Apalagi dengan wajah konsep kesejahteraan Indonesia yang harus dilihat berbeda, terutama dengan konsep lahir batin, bahwa hal apapun tidak bisa hanya diukur dengan nilai atau fakta yang sangat materil (Hidayat, $2001: 11$ ).

Dalam kenyataannya, terjadi suasana yang saling mendominasi karena sesuatu diukur dengan tidak mempertimbangkan berbagai aspek. Hukum negara sering memakai kacamata kuda yang tidak melihat kanan-kiri kehidupan masyarakatnya. Kondisi inilah yang menimbulkan ketidakcocokan dalam pengaturannya.

Ketidakcocokan tersebut, pada akhirnya akan membawa petaka tidak hanya membawa implikasi bagi keberlanjutan lingkungan semata. Lebih jauh, suasana tersebut berimplikasi kepada makin terpinggirnya hukum masyarakat yang mana mereka tidak meninggalkan peta metajuridis dalam pengonsepsian dan pelaksanaannya. 


\section{B. Hukum Negara Memberi Ruang Penggunaan Mini Trawl}

Dari penjelasan di atas, terlihat adanya hubungan keberlakuan dominasi positivisme hukum terhadap hukum lokal (dalam hal ini hukum adat) terkait dengan pengaturan alat tangkap, khususnya minitrawl.

Dalam hukum negara, penggunaan minitrawl diberi ruang untuk digunakan. Hukum negara sekaligus memperlihatkan kondisi kontradiktif. Undang-Undang Perikanan secara eksplisit menegaskan agar sumberdaya perikanan dimanfaatkan secara hati-hati demi keberlanjutan. Namun dalam aturan pelaksana, khususnyarealisasi Keputusan Menteri Kelautan dan Perikanan No. Kep.06/MEN/2010 tentang Alat Penangkapan Ikan di Wilayah Pengelolaan Perikanan Negara Republik Indonesia, memberi ruang bagi penggunaan trawl. Peraturan tersebut, menetapkan adanya 10 kelompok alat penangkap ikan yang boleh digunakan di Wilayah Pengelolaan Perikanan Negara Republik Indonesia, yakni:

1) jaring lingkar (surrounding nets);

2) pukat tarik (seine nets);

3) pukat hela (trawls);

4) penggaruk (dredges);

5) jaring angkat (lift nets);

6) alat yang dijatuhkan (falling gears);

7) jaring insang (gillnets and entangling nets);

8) perangkap (traps);

9) pancing (hooks and lines); 
10) alat penjepit dan melukai (grappling and wounding).

Dengan pengaturan tersebut, tampak bahwa beberapa jenis alat tangkap yang dapat digolongkan ke dalam trawl, diperbolehkan dipergunakan. Pengaturan tersebut menimbulkan perdebatan, terutama dengan adanya Keputusan Presiden Nomor 39 Tahun 1980 tentang Larangan Trawl. Filosofi lahirnya peraturan ini dalam rangka pembinaan kelestarian sumber perikanan dasar dan dalam rangka mendorong peningkatan produksi yang dihasilkan oleh para nelayan tradisional serta untuk menghindarkan terjadinya ketegangan sosial.

Pengaturan jalur penangkapan ikan melalui Keputusan Menteri Pertanian No. 694 Tahun 1980, pada dasarnya adalah kesadaran pemerintah dari dampak alat tangkap yang merusak lingkungan.Hanya saja keberadaan Keppres tersebut dipermasalahkan. Mengingat Keppres tersebut, berlandaskan Pasal 15 Ordinansi Perikanan Pantai Staatsblad Nomor 144 Tahun 1927. Setelah kemerdekaan, beberapa hal yang terkait dengan kekosongan hukum masih menggunakan landasan Pasal 15 tersebut disebabkan belum ada undang-undang yang mengatur perikanan. Namun setelah disahkan Undang-Undang No. 9 Tahun 1985 tentang Perikanan, keberadaan landasan tersebut dipermasalahkan.

Terlepas bagaimana perdebatan tersebut berlangsung, yang mengemuka adalah ruang hukum negara kemudian melahirkan dampak yang tidak sederhana. Kajian Sulaiman dkk (2010 : 1-2), menggambarkan kawasan pesisir barat Indonesia selama ini dikepung oleh empat corak penggunaan trawl, yakni: Pertama, penggunaan pukat trawl yang ilegal dilakukan oleh kapal nelayan asing yang mencuri ikan di perairan barat 
Indonesia. Kedua, penggunaan pukat trawl oleh kapal asing berdasarkan izin tertentu untuk melakukan penangkapan ikan di wilayah perairan Indonesia. Ketiga, penggunaan pukat trawl dari kapal-kapal yang berasal dari wilayah Provinsi yang berbatasan langsung dengan provinsi paling barat. Keempat, nelayan lokal di pesisir barat Aceh yang menggunakan trawl modifikasi dengan nama minitrawl.

Menurut M. Adli Abdullah dkk (2012:37-46), penggunaan pukat trawl atau minitrawl berpotensi menimbulkan implikasi negatif, antara lain: Pertama, penggunaan minitrawl disadari betul akan mengancam ekosistem laut. M. Adli Abdullah menggambarkan, di pesisir barat Aceh yang menggunakan minitrawl, benih-benih ikan yang turut terjaring tetapi tidak dikehendaki, dibuang begitu saja. Bahkan ikan-ikan yang masih kecil itu tidak bisa dimanfaatkan masyarakat sekitar untuk dikonsumsi. Nelayan pengguna minitrawl hanya mengambil ikan-ikan yang laku dijual atau layak dikonsumsi.

Pada kawasan yang didominasi nelayan kecil yang masih menggunakan pukat darat, dampak tersebut secara langsung bisa dirasakan mereka. Pukat darat umumnya digunakan oleh nelayan kecil yang tidak memakai kapal. Pukat tersebut diturunkan ke laut paling jauh 300 meter, kemudian kedua sisi ujungnya ditarik oleh beberapa orang ke arah darat. Bagi nelayan pukat darat tersebut, selama trawl (khususnya mini-trawl yang beroperasi hingga dekat pantai) beroperasi, hasil yang didapat mereka berkurang drastis. Padahal nelayan pukat darat tersebut tidak memiliki pilihan, karena mereka tidak bisa menebar pukat hingga lebih jauh dari 300 meter ke arah laut. Berbeda dengan nelayan yang menggunakan kapal, mereka dapat bergerak sesuai dengan kehendak dan potensi ikan di laut (Syaref, $2003: 12$ ). 
Di samping itu, kerusakan terumbu karang juga akibat penggunaan pukat minitrawl, mengakibatkan fungsi ekosistem laut tidak berjalan sebagaimana mestinya. Keberadaan terumbu karang akan membantu nelayan kecil dekat dengan ikan. Kehancuran terumbu karang menyebabkan ikan juga bergeser semakin jauh dari pesisir (Subekti, 2013).

Kedua, penggunaan minitrawl dapat menjadi bentuk pengingkaran terhadap hukum lokal yang sangat arif dalam memperlakukan dan mendudukkan fungsi lingkungan hidup. Masyarakat Indonesia memiliki hukum lokal yang beraneka ragam (Abdullah dkk, 2006 : 36; Usman, 2011 : 2-3; Usman, 2013 : 5). Hukum lokal laut tersebut melarang penggunaan segala jenis alat tangkap yang destruktif terhadap ekosistem. Semua alat tangkap yang menghancurkan atau menganggu fungsi lingkungan hidup tidak boleh digunakan oleh masyarakat.

Keberadaan kearifan lokal dalam pengelolaan perikanan di Indonesia mendapat khusus dan diatur dalam UU Perikanan dan UU Pemerintahan Aceh. Pasal 6 UU No. 45 Tahun 2009 menentukan bahwa pengelolaan perikanan harus memperhatikan kearifan lokal. Pasal 162 ayat (2) huruf e UU No. 11 tahun 2006 menegaskan, Pemerintah Aceh dan Pemerintah Kabupaten/Kota di Aceh berwenang mengelola sumberdaya alam yang hidup di laut wilayah Aceh, antara lain meliputi pemeliharaan hukum adat laot.

Ketiga, dengan penjelasan pertama dan kedua, maka selain ada pemakai minitrawl, dalam kenyataan banyak juga nelayan yang memperlakukan ekosistem laut secara santun. Alasan ini menyebabkan penggunaan minitrawl menimbulkan pro-kontra 
di kalangan nelayan. Sebagian nelayan kecil memandang minitrawl menimbulkan implikasi negatif dalam merusak ekosistem, makanya harus dilawan, maka seyogianya penggunaannya harus dihentikan. Sedangkan nelayan yang menggunakan minitrawl merasakan bahwa alat yang mereka gunakan tidak melanggar hukum dan memberi keuntungan secara ekonomis, sehingga bersikeras akan terus menggunakan meskipun ada nelayan yang menolak. Kondisi tersebut memunculkan konflik antara pengguna minitrawl dan yang menolak. Nelayan yang menolak minitrawl beberapa kali melakukan razia terhadap pengguna minitrawl, karena beralasan bahwa berbagai dampak pada akhirnya turut dirasakan oleh mereka. Secara sosial, konflik fisik menyebabkan bencana secara sosial, yang sudah seharusnya pemerintah tanggap akan kenyataan tersebut.

Ketiga hal di atas dapat menjadi fakta bahwa secara ekologi-ekonomi dan sosialbudaya, penggunaan minitrawl membawa kemudharatan. Kondisi tersebut sudah seharusnya membuat pemerintah melakukan langkah-langkah penanggulangannya.Namun demikian secara hukum langkah pemerintah bisa dipermasalahkan karena pengaturan tentang alat tangkap oleh hukum negara yang tidak jelas. Makanya dalam masyarakat penggunaan minitrawl, baik secara sembunyi-sembunyi maupun terang-terangan, terus berlangsung.

Gambaran di atas, tampak ada suasana persinggungan sesama hukum. Secara normatif, peraturan perundang-undangan melarang penggunaan alat tangkap yang tidak ramah lingkungan, dalam rangka keberlanjutan lingkungan. Dalam hal ini, tentu saja termasuk alat tangkap jenis trawl, namun di pihak lain, peraturan perundang-undangan 
pula yang memberi ruang alat tangkat yang merusak seperti trawl atau minitrawl yang jelas berdampak pada lingkungan, diperbolehkan untuk dipergunakan.

Ruang demikian merupakan pengingkaran dari kebijakan makro pembangunan Indonesia. Dalam UU Nomor 17 Tahun 2007 tentang Rencana Pembangunan Jangka Panjang Nasional Tahun 2005-2025, disebutkan bahwa sumberdaya alam laut harus dimanfaatkan secara optimal. Namun demikian ditekankan bahwa kearifan lokal sangat diperlukan untuk menjamin sumberdaya alam dan pelestarian lingkungan hidup. Salah satu visi pembangunan adalah pemerataan pembangunan dan pemerataan serta perwujudan Indonesia asri dan lestari. Dalam hal ini, membaiknya pengelolaan sumberdaya alam dan fungsi lingkungan hidup, termasuk kesadaran, sikap mental, dan perilaku. Pendekatan pengelolaan perikanan ditekankan pada perpaduan antara ekonomi, sosial, dan lingkungan.

Kebijakan Makro Pembangunan kelautan dan perikanan secara berkelanjutan memerlukan keterpaduan pembangunan pada masing-masing sektor. Kebijakan komprehensif di bidang kelautan dan perikanan yang meletakkan prinsip keadilan (equity), demokratisasi dan peningkatan kesejahteraan masyarakat tersebut menjadi sebuah kebutuhan yang mendesak. Dalam rangka meningkatkan semangat keterpaduan pembangunan kelautan dan perikanan, arah kebijakan makro pembangunan bidang Kelautan dan Perikanan antara lain: (a) menyatukan komitmen politik dari para penentu kebijakan dalam mengedepankan pembangunan kelautan dan perikanan dan perlu menyusun Undang-Undang Kelautan Nasional yang sinergi dan terintegrasi; (b) meningkatkan pemahaman pentingnya laut dari aspek geopolitik dan geostrategis kepada 
seluruh komponen. Selain itu juga armada pengamanan laut perlu di perkuat dan ditambah baik kualitas maupun kuantitasnya dalam kaitannya untuk menjaga keutuhan NKRI dan keutuhan sumber daya alam; (c) mengatasi masalah kerusakan lingkungan di wilayah pesisir, dilakukan rehabilitasi lahan pesisir yang sudah terdegradasi, memperluas daerah-daerah perlindungan bagi spesies yang langka dan menindak tegas para perusak lingkungan.

Selama ini, Rejim pengelolaan sumber daya kelautan dan perikanan dapat digolongkan menjadi tiga tipe, yaitu: rejim pengelolaan berbasis pemerintah (state property regime), berbasis swasta (private property regime) dan masyarakat (communal property right). Dalam konteks kelembagaan, property right (private, public/state, communal) merupakan institusi sosial yang penting dalam pertumbuhan ekonomi dan perlindungan terhadap sumber daya alam. Dalam prakteknya untuk kepentingan pembangunan ekonomi, public property right dan private property right lebih dominan dibanding communal property right yang tujuannya lebih memberikan hak-hak eksklusif terhadap suatu komunitas yang di dalamnya mengandung konvensi sosial, norma, aturan-aturan yang ditegakan secara legal, dan prosedur-prosedur yang mengatur pemanfaatannya. Oleh karena itu, kelembagaan dalam konteks desentralisasi dan otonomi pengelolaan sumberdaya kelautan dan perikanan harus dilihat sebagai bentuk pengelolaan bersama pada level global, nasional, regional dan lokal. Khusus di level lokal, pengelolaan bersama harus mempertimbangkan hak masyarakat lokal, hukum adat, institusi dan kearifan lokal dalam masyarakat sebagai wujud partisipasi dan kemandirian masyarakat dalam pengelolaan sumberdaya kelautan dan perikanan. 


\section{Langkah Pemerintah Menanggulangi Trawl}

Dalam lingkup lokal, terdapat lima Arah Kebijakan penting, sebagai penentuan arah kebijakan strategis berdampak pemerataan akibat peningkatan kesejahteraan melalui pengelolaan, pengendalian dan pengawasan sumberdaya kelautan dan perikanan yang terintegrasi di Indonesia, yakni: (a) menciptakan kesempatan kerja bagi masyarakat di wilayah pesisir melalui diversifikasi jenis usaha; (b) melaksanakan pengawasan dan pengendalian sumberdaya pesisir, kelautan dan perikanan melalui peningkatan koordinasi dengan lintas sektor; (c) melakukan percepatan revitalisasi melalui pembangunan / pengembangan sarana dan prasarana pokok perikanan tangkap dan budidaya; (d) pengembangan dan pengelolaan sumberdaya kelautan; dan (e) pengembangan sumber daya perikanan (Sulaiman, $2010: 126$ ).

Arah kebijakan sebagaimana tersebut di atas, dipandang selaras dengan tujuan pengelolaan perikanan yang dimaksud UU Perikanan, mencakup: (1) meningkatkan taraf hidup nelayan kecil dan pembudi daya ikan-kecil; (2) meningkatkan penerimaan dan devisa negara; (3) mendorong perluasan dan kesempatan kerja; (4) meningkatkan ketersediaan dan konsumsi sumber protein hewani; (5) mengoptimalkan pengelolaan sumber daya ikan; (6) meningkatkan produktivitas, mutu, nilai tambah, dan daya saing; (7) meningkatkan ketersediaan bahan baku untuk industri pengolahan ikan; (8) mencapai pemanfaatan sumber daya ikan, lahan pembudidayaan ikan, dan lingkungan sumberdaya ikan secara optimal; dan (9) menjamin kelestarian sumber daya ikan, lahan pembudidayaan ikan, dan tata ruang. 
Arah kebijakan memperhatikan kondisi ideal, khususnya menghadapi dampak yang ditimbulkan dari kegiatan destruktif. Namun demikian dalam menyahuti arah kebijakan tersebut, kerapkali tindakan pemerintah hanya dilakukan pada tahap meredam saja, tidak secara substansi menyelesaikan masalah. Tindakan tersebut berada di puncak dan terlihat gamblang. Seperti puncak gunung es, justru masalah besarnya adalah dasar yang tidak kasat mata.

Tindakan-tindakan yang minus substansi, misalnya, dengan melakukan hal-hal yang sesungguhnya hanya menyelesaikan efek, tidak menyelesaikan permasalahan secara mendasar. Umumnya, tindakan yang dibutuhkan tersebut tidak terlihat jelas, melainkan harus dikaji dan dianalisis.

Persoalan mendasar adalah adanya pengaturan hukum negara yang sangat mendominasi hukum lokal. Sementara dalam praktek meredam implikasi, yang dilakukan pemerintah umumnya hanya dengan membentuk tim teknis (termasuk pengawas), melakukan sosialisasi, atau bahkan menggantikan alat tangkap. Sementara hukum negara yang sesungguhnya memberi ruang, tidak disentuh untuk direkonstruksi.

Di beberapa daerah pesisir, pola kebijakan tersebut berjalan. Namun substansi bahwa dalam aturan pelaksana memberikan ruang penggunaan alat tangkap yang tidak ramah lingkungan, tidak dilihat sebagai sumber masalah.

Kebijakan semacam itu dasarnya hanya untuk meredam sesaat, bukan untuk menyelesaikan masalah jangka panjang. Program yang sifatnya meredam tersebut, kadangkala juga ditimbulkan oleh adanya tekanan-tekanan yang muncul dari luar pemerintah sendiri. Dalam hal ini misalnya adanya tekanan masyarakat yang sudah 
berkonflik secara fisik, sehingga pemerintah mengantisipasi dalam rangka menyelesaikan konflik. Sedangkan masalah inti yang menyebabkan konflik, dibiarkan saja.

Kondisi tersebut dimungkinkan terjadi, antara lain dalam menentukan penataan alat tangkap, sangat dipengaruhi oleh apa yang disebut dengan bekerjanya sistem hukum dalam masyarakat. William J. Chamblis dan Robert Siedman menyebutkan, bekerjanya hukum dalam masyarakat ditentukan oleh lembaga pembuat hukum (rule making institution), lembaga penerap sanksi (rule sanctioning institution), dan pemegang peran (rule occupant) yang dipengaruhi oleh kekuatan masyarakat dan individu atau kekuatan sosial. Pemegang peran hukum melakukan umpan balik (feedback) pada lembaga pembuat hukum untuk menghasilkan norma yang lebih baik, dimana kemudian dilakukan penerapan oleh lembaga penerap sanksi (Chambliss and Siedman, 1971 : 9-13; Warassih, $2005: 11-12$ ).

Terdapat suatu perkembangan kondisi bagaimana rule making institutions, rule sanctioning institutions, dan rule occupant itu saling memberi respon dan umpan balik. Apa yang disebut dengan norma, dan umpan balik sebagai bagian penting dalam hubungan ketiga institusi tersebut, dipengaruhi pula oleh kekuatan individu dan sosial.

Dengan demikian, proses bekerjanya sistem hukum berkaitan dengan tindakan pemerintah adalah sebagai berikut:

1) Beberapa peraturan yang dihasilkan, dari peraturan paling dasar hingga paling konkret (aturan pelaksana) termasuk kebijakan yang dihasilkan di daerah, seyogianya konsisten, koheren, dan saling berinteraksi agar tidak menimbulkan kenyataan yang tidak diinginkan. Adanya peraturan yang melenceng dari konsep 
Available online at: http://ejournal.unpas.ac.id/index.php/litigasi

Litigasi, Vol. 17(2), 2016, 1377 - 3426

DOI: http://dx.doi.org/10.23969/litigasi.v17i2.139

konsisten dan koheren tersebut, menimbulkan permasalahan pada masyarakat yang akhirnya berimplikasi kepada berbagai masalah ikutannya.

2) Setiap sistem hukum mempengaruhi kegiatan, yang dalam kenyataan tampak bahwa apa yang dilakukan pemerintah seringkali merupakan respon untuk menjawab tekanan-tekanan tertentu.

3) Ada proses pengajuan tuntutan untuk mewujudkan hukum yang lebih baik, yang menggambarkan bahwa harapan hukum untuk mengatur alat tangkap yang ramah lingkungan, oleh masyarakat sangat besar.

4) Dalam hal ini, hanya negara yang memiliki kewenangan lebih dalam hal mengatur pemanfaatan sumberdaya perikanan, yang sebagian pola pemilikan dapat diserahkan melalui pengelolaan berbasis kearifan lokal.

5) Adanya atau tidaknya pengaturan yang berpihak oleh negara, kemudian akan diberikan respon oleh para pemegang peran masing-masing.

6) Lembaga-lembaga yang melaksanakan dipengaruhi oleh kekuatan-kekuatan sosial dan personal.

Gambaran tersebut di atas, memperjelas bahwa dalam melakukan penataan alat tangkap oleh pemerintah, sangat dipengaruhi oleh bekerjanya sistem hukum, yang ditentukan oleh pihak-pihak yang telah disebutkan di atas. Seyogianya dengan adanya umpan balik yang lebih baik, akan menghasilkan hukum yang lebih baik dengan pola interaksi antara hukum negara dan hukum lokal tidak lagi dalam posisi saling mendominasi, melainkan saling melengkapi.

Copyright @ 2016, LITIGASI, p-ISSN: 0853-7100; e-ISSN: 2442-2274 
Available online at: http://ejournal.unpas.ac.id/index.php/litigasi

Litigasi, Vol. 17(2), 2016, 1377 - 3426

DOI: http://dx.doi.org/10.23969/litigasi.v17i2.139

D. Interaksi Hukum Negara dan Hukum Lokal dalam Penanggulangan Trawl

Konsep pemanfaatan sumberdaya perikanan mengacu pada proses pengelolaan yang bertujuan mencapai sebesar-besar kemakmuran rakyat. Pencapaian tersebut idealnya tidak meninggalkan pola kearifan lokal, sebagai upaya memanfaatkan sumberdaya perikanan secara lestari dan berkelanjutan. Dengan pemanfaatan demikian, penting bagi negara untuk membangun paradigma ekonomi yang tidak hanya mengejar pertumbuhan, namun juga mengedepankan prinsip keadilan sosial dan keberlanjutan lingkungan. Pembangunan ekonomi harus menghadirkan kesejahteraan untuk kemakmuran rakyat.

Dengan konsep demikian, mengharuskan negara untuk pro aktif memberantas berbagai bentuk kejahatan lingkungan hidup bidang kelautan dan perikanan, yang mengancam keberlangsungan ekosistem laut dan keberlanjutan sumberdaya yang dikandungnya.

Konsep demikian, dalam implementasinya dilakukan dalam berbagai tingkatan kebijakan. Kebijakan makro pengelolaan perikanan global sebenarnya telah selaras dengan kebijakan lokal yang mengakomodir kearifan lokal. Kebijakan tersebut kemudian diturunkan dalam pengelolaan perikanan nasional. Dalam lingkup lokal, kebijakan yang sama juga sudah ditentukan.

Dalam suasana interaksi ekstrem, hukum negara dan hukum lokal akan bersitegang. Namun kondisi ideal sebenarnya adalah mengakomodasi kemajemukan normatif yang hidup, dianut, dan dioperasikan masyarakat lokal dengan sistem 
hukumnya (self regulation) yang dikenal sebagai hukum adat, seyogianya dipayungi (Nurjaya, $2008: 40$ ).

Keberadaan hukum lokal dalam masyarakat lokal tersebut berdasar pada nilai-nilai yang hidup, tumbuh, dan berkembang dalam masyarakat, walau tidak diukur rasional sebagaimana hukum modern, hal ini dikarenakan hukum lokal berasal dari hukum agama, tradisi, dan kepercayaan. Sistem seperti ini berlangsung dalam konteks yang tidak mungkin bebas atau netral dari pengaruh moral dan agama. Berseberangan (atau bahkan berbenturan) dengan konsep hukum modern yang selama ini dipelajari secara umum pada perguruan tinggi, yang menurut Roberto M. Unger, membutuhkan keambrukan tatanan tradisional (Rahardjo, 2006 : 112).Konsep hukum modern tersebut, bisa menjadi alasan pemerintah tidak menempatkan hukum lokal pada posisi sangat penting. Padahal hukum lokal adalah hukum yang menyatu dengan masyarakatnya.

Apa yang diharapkan di atas, bukan merupakan sesuatu yang tidak mungkin. Gustav Radbruch sebenarnya sudah mengingatkan akan hal ini. la menyebutkan bahwa hukum itu, pada dasarnya ada yang ideal dan ada yang kenyataan, dengan corak penerimaan yang berbeda. Hukum yang ideal seyogianya meramu dua kondisi tersebut, dengan prasyarat tidak meninggalkan apa yang dinamakan moral dan kebiasaan.

Dengan demikian, hukum harus meramu dua dunia yang berbeda bahkan bertentangan. la harus mengambil keputusan berdasarkan otoritasnya sendiri, dan berpedoman kepada apa yang dikehendaki. Pencerminan dari keterikatan hukum kepada kedua dunia tersebut tampak pada berlakunya hukum dalam masyarakat (Rahardjo, $2006: 16)$

Copyright $\odot$ 2016, LITIGASI, p-ISSN: 0853-7100; e-ISSN: 2442-2274 
Satjipto Rahardjo mengingatkan bahwa antara yang ideal dan yang kenyataan acapkali menimbulkan ketegangan satu sama lain. Hukum menjadi sangat berat tugasnya meramu dua dunia yang memiliki ketegangan tinggi tersebut (Rahardjo, $2006: 16-18$ ).

Kondisi potensi ketegangan (spannungsverhaltnis), diungkapkan Gustav Radbruch melalui tiga nilai dasar hukum, yakni kepastian hukum, kegunaan, dan keadilan. Ketegangan ketiganya bisa dimengerti karena ketiga-tiga nilai dasar tersebut berisi tuntutan yang berlainan (Rahardjo, $2006: 19$ ).

Kondisi hukum negara dan hukum lokal, mewakili dari masing-masing nilai dasar yang dimaksudkan. Hukum negara lebih mengejar kepastian hukum, sebaliknya hukum lokal lebih menekankan pada aspek kegunaan. Makanya para ahli hukum kemudian harus memahami adanya perbedaan yang dimaksud dalam wujud hukum-hukumnya yang khas.

Wujud yang responsif bisa muncul dalam kondisi yang saling memahami. Dalam hal ini, posisi hukum negara dan hukum lokal untuk berusaha saling melengkapi dalam wujud hukum yang baru yang plural dan mengabdi bagi kepentingan masyarakat banyak. Tipe yang oleh Philippe Nonet dan Philip Zelznick, tergolong dalam tipe responsif. Dalam hubungannya dengan tertib sosial dan tertib politik, tipe hukum responsif sepadan dengan tipe organisasi formal terkait birokrasi, dalam wujud post-birokratik (Nonet dan Zelznick, 2008 : 18-32).

Pemahaman demikian dibutuhkan di tengah suasana hukum negara yang kerap arogan terhadap hukum lokal. Beberapa kajian menggambarkan arogansi itu, misalnya kajian Anto Achaliat, Dominikus Rato, dan Bernard L. Tanya. 
Dominikus Rato mengkaji hukum yang berkenaan dengan tanah dalam kosmologi masyarakat Osing. Kepercayaan-kepercayaan tersebut bagi hukum positif merupakan sesuatu yang tidak masuk akal. Sedangkan Bernard L. Tanya, menggambarkan betapa hukum negara tidak selalu bisa menjadi jalan keluar dalam menyelesaikan persoalan dalam masyarakat. Konsep hukum positif tidak selalu bisa menjadi solusi atas persoalan yang timbul dalam masyarakat (Achadiat, 1993 : 177; Rato, 2009 : 167; Tanya, $2000: 126)$.

Kondisi ideal interaksi adalah mengakomodasi kemajemukan normatif yang hidup, dianut, dan dioperasikan masyarakat lokal dengan sistem hukumnya (Nurjaya, 2008: 40). Hukum lokal tersebut berdasar pada nilai-nilai yang hidup, tumbuh, dan berkembang dalam masyarakat, walau tidak diukur rasional sebagaimana hukum modern, hal ini dikarenakan hukum lokal berasal dari hukum agama, tradisi, dan kepercayaan.

Werner Menski menawarkan suatu interaksi hukum baru yang seyogianya menjadi jalan keluar, melalui gagasan pluralisme hukum baru, dengan wujud kombinasi antara state law (positivism), society (socio-legal approach), dan natural law (moral/ethic/religion) (Suteki, 2013 : 195). Menski memperlihatkan bahwa dalam operasionalnya, state law, society, dan natural law, memiliki kekuatan dan kebenaran masing-masing (Menski, 2006 : 185-187).

Menurut Menski, harus ada perkembangan, dimulai dari tepian segitiga yang sama-sama memiliki ruang, namun didominasi sekali oleh negara, dengan sedikit pun tanpa memperhatikan hukum adat dan kearifan lokal. Apa yang menjadi khas dari negara, misalnya dalam wujud transplantasi, maka ia menjadi dominan. Sementara pada 
ruang yang kedua, sudah ada kesalingpengaruh dalam melakukan hubungan, walau negara masih tetap berada pada posisi yang dominan. Sedangkan ruang ketiga adalah kondisi ideal, dimana satu sama lain sudah saling membuka diri untuk saling melengkapi.

Harapan tersebut memungkinkan dicapai, antara lain dengan kesediaan untuk mengubah orientasi pembangunan yang tidak lagi hanya berorientasi mengejar pertumbuhan ekonomi semata (Nurjaya, 2007 : 13). Ada hal lain yang harus dilihat, yakni keadilan sosial. Berkenaan dengan modernisasi alat tangkap, orientasi pembangunan yang berkeadilan sosial harus menjadi dasar pijakan, agar sumberdaya perikanan tidak hanya dipandang sebagai alat memenuhi manfaat ekonomi semata, karena melekat nilai, budaya, spritual, sosial, politik, dan ekologis (Titahelu, 2005 : 198). Inilah yang disebut moralitas ekologis (Keraf, 2005 : 284).

Berkaitan dengan itu, Keraf menyebut tujuh prinsip etika dalam lingkungan yang penting untuk diperhatikan: yaitu:

1) sikap hormat pada alam;

2) tanggung jawab;

3) solidaritas kosmis;

4) kasih sayang dan kepedulian alam;

5) tanggung jawab dan kewajiban moral terhadap alam;

6) hidup sederhana dan selaras dengan alam, dan

7) keadilan (Keraf, $2005:$ 144-159).

Dalam kacamata ini, alam bukan sekedar dieksploitasi untuk dimanfaatkan. Corak teknokratis yang disebut Franz Magnis Suseno, dalam wujud antroposentrisme, sudah 
harus ditinggalkan. Antroposentrisme adalah pandangan manusia terhadap lingkungan hidup yang menempatkan kepentingan manusia dipusatnya. Dale T. Snauwaert menyebut pandangan antroposentrisme menolak keberadaan nilai-nilai instrinsik alam, halmana sejalan dengan pendekatan teknokratis. Keraf menulis, cara pandang antroposentris melahirkan sikap dan perilaku eksploitatif tanpa kepedulian sama sekali terhadap alam dengan segala isinya, yang dianggap tidak mempunyai nilai pada dirinya sendiri(Hidayat dan Samekto, 2005 : 27).

Cara pandang baru yang ditawarkan adalah deep ecology, dengan melibatkan semua entitas kehidupan tanpa ada yang tercecer, mulai dari organisme, sistem sosial, dan lingkungan, semua terhubung secara holistik dalam suatu kesatuan yang tidak bisa dipisahkan satu sama lain. Model ini digunakan Capra dalammemetakan masalah manusia. Capra menggunakan 'ecology' sebagai cermin bahwa ekosistem harus dilihat dengan holistik. Masalah pertumbuhan penduduk, yang oleh Malthus disebut dengan istilah pelipatgandaan manusia, merupakan masalah yang tidak bisa dipisahkan dari hal ini. Intinya adalah tentang holistik bahwa cara pandang baru terhadap sesuatu masalah, tidak bisa dilepaskan dengan masalah lain yang selalu berkaitan dengannya. Cara pandang ini kemudian dipadukan dengan saling berhubungan dengan proses pemahaman, penjelasan, hingga pemecahan masalah (Capra, 2001 : 102).

Cara pandang lingkungan seperti inilah yang ditawarkan sebagai model interaksi ideal antara hukum negara dan hukum lokal dalam penanggulangan trawl. Dengan model demikian, apa yang menjadi konsep kesejahteraan dalam Pasal 33 ayat (3) UUD 1945, tidak dipahami dengan proses eksploitasi. Pemerintah harus menyelami cara pandang 
masyarakat lokal dengan kearifan lokalnya terhadap kesejahteraan, salah satunya adalah terkait dengan kenyamanan melakukan penangkapan ikan di wilayahnya, bukan pada besar-kecilnya. Satjipto Rahardjo menyebutkan bahwa dalam UUD kita jumpai kaidahkaidah atau asas-asas umum apa yang disebut Satjipto Rahardjo sebagai teks moral, antara lain: bumi, air, kekayaan alam dipergunakan untuk sebesar-besar kemakmuran rakyat, perekonomian didasarkan atas asas kekeluargaan, dan produksi untuk hajat hidup orang banyak dikuasai negara (Rahardjo, 2007 : 57-58). Konsep demikian, sekaligus mewakili cara pandang masyarakat lokal terhadap kelestarian dan keberlanjutan lingkungan (Hardjasoemantri, $2005: 12-13$ ).

Kesadaran demikian patut dimunculkan kembali di tengah kegersangan moral dan etika. Kerangka pandang holistik masyarakat lokal, sudah seyogianya menjadi pemandu kebijakan perikanan, untuk tidak melihat ekonomi sebagai satu-satunya konsep kesejahteraan. Kesejahteraan dalam bentuk lain menjadi sangat penting, berupa dampak beban sosial yang dihadapi dari kondisi kerusakan sumberdaya perikanan.

Dalam memperlakukan lingkungan, konsep keadilan tidak melupakan dampak berupa beban sosial tersebut. Memang keadilan diartikan sebagai kemauan yang bersifat tetap dan terus-menerus untuk memberikan kepada setiap orang apa yang seharus ia terima. Namun peran hukum seyogianya membuat posisi keadilan menjadi berbeda, yakni mewujudkan ide keadilan ke dalam bentuk konkret agar dapat memberi manfaat bagi hubungan antarmanusia (Samekto, 2008 : 6-7).

Dalam pernyataan masyarakat adat disebutkan bahwa Indonesia sebagai negara kepulauan memiliki akar sejarah yang kuat di bidang kelautan dan perikanan. Dalam 
pada itu, laut dipahami masyarakat nelayan tradisional sebagai way of life yang mewadahi seluruh tata sosial kemasyarakatan, pendidikan, etika, dan moral masyarakat, bukan hanya ruang untuk mencari nafkah.

International Collective in Support of Fishworkers (ICSF) melaksanaan Workshop on Customary Knowledge and Fisheries Management Systems in Southeast Asia di Mataram (2-5 Agustus 2009), sekaligus melahirkan Deklarasi Lombok di bidang perikanan dan kelautan serta hak-hak nelayan tradisional yang dicetuskan di Lombok, Nusa Tenggara Barat pada 6 Agustus 2009. Deklarasi itu merupakan kesepakatan akhir dari 62 peserta lokakarya se-Indonesia pada tanggal 2-5 Agustus, kemudian dilanjutkan dengan simposium pada 6 Agustus 2008 di Lombok. Dihadiri perwakilan masyarakat hukum adat, nelayan tradisional, masyarakat pesisir, perempuan nelayan, masyarakat peduli lingkungan hidup, gerakan masyarakat sipil, dan akademisi.

Perwakilan masyarakat hukum adat meyakini bahwa tata hukum adat dan pengetahuan tradisional memberi kontribusi amat sangat besar terhadap keberlangsungan ekosistem laut dan pesisir, keberlanjutan sumber daya laut dan perikanan yang dikandungnya, serta kelestarian lingkungan hidup. Mereka telah membuktikan bahwa tata hukum adat dan pengetahuan tradisional telah memberi sumbangsih teramat sangat besar dalam pengelolaan sumber daya kelautan dan perikanan yang adil dan berkelanjutan sejak abad XVI. Mereka juga mempercayai bahwa dengan memperkuat modal sosial dan budaya, akses, dan kontrol masyarakat hukum adat, nelayan tradisional, dan masyarakat pesisir dalam mengelola sumber daya kelautan dan perikanan 
merupakan titik temu yang mampu memulihkan krisis multidimensi yang berlangsung hingga saat ini.

Masyarakat hukum adat menyakini bahwa pengelolaan sumber daya laut dan pesisir haruslah mengedepankan nilai keadilan sosial. Masyarakat adat menuntut dihentikannya praktek privatisasi, monopoli, dan liberalisasisumber daya kelautan dan pesisir, Peraturan Menteri Kelautan dan Perikanan No. 5 Tahun 2008 yang telah direvisi menjadi Peraturan Menteri Kelautan dan Perikanan No. 12 Tahun 2009 tentang Perikanan Tangkap, khususnya aturan terkait Kluster Perikanan; serta dikedepankannya hak konstitusional masyarakat hukum adat yang selaras dengan prinsip-prinsip universal yang dijamin dalam UUD 1945, Universal Declaration of Human Rights, International Covenant on Civil and Political Rights, International Covenant on Economy, Social and Cultural Rights, dan Declaration on the Rights of Indigenous Peoples, serta UndangUndang No. 39 Tahun 1999 tentang Hak Asasi Manusia. Mereka menuntut diprioritaskannya kepentingan lembaga hukum adat di atas kepentingan investor dan lembaga konservasi internasional, melalui Forum Komunikasi Lembaga Adat.

Cita-cita yang diharapkan adalah lahirnya pengakuan konstitutif terhadap kewenangan lembaga hukum adat dalam pengelolaan sumber daya kelautan dan perikanan. Penguatan lembaga adat yang dimaksudkan adalah:

1) Negara mengakui, memenuhi, dan melindungi nilai-nilai luhur yang terkandung dalam tata laksana hukum adat dan pengetahuan tradisional yang telah berlangsung turun-temurun, sebagai bagian dari identitas budaya bangsa yang telah terbukti memberi sumbangsih pada praktek konservasi sumber daya 
Available online at: http://ejournal.unpas.ac.id/index.php/litigasi

Litigasi, Vol. 17(2), 2016, 1377 - 3426

DOI: http://dx.doi.org/10.23969/litigasi.v17i2.139

kelautan dan perikanan, serta memberi jalan bagi penyelesaian konflik antarkomponen masyarakat. Upaya ini bisa dilakukan dengan cara mengadopsi tata laksana hukum adat dan pengetahuan tradisional dalam sistem hukum nasional.

2) Negara harus mengedepankan prinsip-prinsip keberlanjutan sumber daya pesisir dan perikanan, dengan tetap memprioritaskan pemenuhan kebutuhan konsumsi domestik yang kian meningkat.

Kebijakan responsif dimungkinkan lahir dari proses kesadaran tersebut. Politik hukum yang dibangun dalam menjawab kebijakan juga selalu berkorespondensi dengan masyarakat.

Sederhananya, interaksi ideal hukum negara dan hukum lokal adalah keterbukaan masing-masing untuk saling berhubungan dalam konteks melengkapi satu sama lain. Dengan kenyataan pluralisme hukum, hukum negara dan hukum lokal harus saling membuka diri dengan tujuan saling melengkapi satu sama lain. 


\section{SIMPULAN DAN SARAN}

A. Simpulan

Berdasarkan uraian bagian sebelumnya, dalam tulisan ini dapat disimpulkan sebagai berikut:

1. Pengaturan mengenai penggunaan alat tangkap minitrawl, tidak lepas dari proses modernisasi alat tangkap dalam pemanfaatan sumberdaya perikanan. Semakin modern alat tangkap dipandang akan semakin mempercepat peningkatan ekonomi masyarakat. Pada sedari awal disadari bahwa proses modernisasi alat tangkap pasti menimbulkan dampak. Salah satu alat tangkap yang diberi ruang oleh hukum negara terkait modernisasi ini adalah trawl, yang karena oleh pihak-pihak kemudian dilakukan modifikasi dalam bentuk minitrawl. Sebagai sebuah kebijakan buah modernisasi, maka pukat trawl turut berdampak pada cara-cara masyarakat lokal menghormati dan melindungi lingkungan. Pada setiap masyarakat memiliki kearifan lokal tersendiri dalam memperlakukan lingkungan. Hukum adat laot memiliki seperangkat ketentuan tidak tertulis untuk melakukan usaha penangkapan ikan dengan alat tangkap yang ramah lingkungan. Hukum adat laut juga memiliki seperangkat sanksi bagi para pelanggaranya. Hukum adat laot memandang bahwa penggunaan alat tangkap tidak ramah lingkungan akan berimplikasi kepada tidak tercapainya tujuan kesejahteraan. Harus diakui ada perbedaan cara pandang hukum negara dan hukum adat mengenai 
Available online at: http://ejournal.unpas.ac.id/index.php/litigasi

Litigasi, Vol. 17(2), 2016, 1377 - 3426

DOI: http://dx.doi.org/10.23969/litigasi.v17i2.139

kesejahteraan yang berimplikasi kepada cara pandang lingkungan. Hukum negara kerap melihat kesejahteraan sebagai sesuatu yang terlihat semata.

2. Tindakan pemerintah mengenai penggunaan alat tangkap minitrawl, umumnya melalui kebijakan jangka pendek. Kebijakan yang dilahirkan untuk meredam berbagai tekanan dan tuntutan dari masyarakat, sementara masalah hakiki berupa peraturan yang memberi ruang penggunaan alat tangkap yang tidak ramah lingkungan, belum terselesaikan.

3. Interaksi ideal hukum negara dan hukum adat dalam penanggulangan penggunaan minitrawl dalam masyarakat adalah keterbukaan masing-masing untuk saling berhubungan dalam konteks melengkapi satu sama lain. Dengan kenyataan pluralisme hukum, hukum negara dan hukum lokal harus saling membuka diri. Secara proses, konsep dimunculkan dari bawah, hingga melahirkan suatu konsep yang secara terbuka sudah dikomunikasikan.

B. Saran

Proses penanggulangan dan pengaturan alat tangkap yang tidak ramah lingkungan tidak bisa dilakukan secara sederhana sebagaimana dalam konsep modernisasi alat tangkap yang terkesan sangat sederhana. Apalagi yang terkait dengan hukum adat dan masyarakat lokal, maka yang harus dilihat tidak hanya materil, tetapi juga immaterial, tidak hanya lahir, tetapi juga batin. Dalam hal ini, program yang responsif membutuhkan dukungan bersama baik negara (eksekutif 
Available online at: http://ejournal.unpas.ac.id/index.php/litigasi

Litigasi, Vol. 17(2), 2016, 1377 - 3426

DOI: http://dx.doi.org/10.23969/litigasi.v17i2.139

dan legislatif), masyarakat, dan stakeholders perikanan, dalam jangka panjang sangat dibutuhkan.

Secara praktis, sangat penting artinya eksekutif dan legislatif membangun komunikasi secara intens untuk mencari solusi problem yang berkaitan dengan penanggulangan dan pengaturan alat tangkap tidak ramah lingkungan. Secara teoritis, konsep hukum adat dan hukum lokal lainnya masih bisa diperdebatkan menyangkut dengan istilah, konsep, dan ruang sosialnya. Namun dalam kenyataan terdapat hukum semacam itu untuk mengatur kehidupan sosial mereka. 


\section{DAFTAR PUSTAKA}

\section{BUKU}

Abdullah et., al., M Adli, 2006, Selama Kearifan adalah Kekayaan, Hukum Adat Laut dan panglima Laot di Aceh, Jakarta: Yayasan Kehati.

Abdullah et.,al., M. Adli, 2012, Pembagian Kewenangan Kelola Laut Aceh, Belajar dari Program Pengelolaan Bersama Perikanan di Aceh, Banda Aceh: Pusat Studi Hukum Adat Laut dan Pengelolaan Perikanan Universitas Syiah Kuala.

Achadiat, Anto, 1993, Penyelesaian Sengketa dan Hancurnya Kekerabatan di Manggarai, dalam Antropologi Hukum: Sebuah Bunga Rampai, Jakarta: Yayasan Obor Indonesia.

Apeldoorn, LJ. Van, 1981, Pengantar Ilmu Hukum (Inleiding tot de Studie van het Nederlandse Rechts), Cetakan ke-18, Jakarta: Prandya Paramita.

Bedner, Adriaan, 2007, Access to Environmental Justice in Indonesia, Netherlands: Koninklijke Brill NV.

Benda-Beckmann, Keebet von, 2005, Pluralisme Hukum, Sebuah Sketsa Genealogis dan Perdebatan Teoritis, dalam Pluralisme Hukum, Sebuah Pendekatan Interdisiplin, Jakarta: HuMa.

Capra, Fitjof, 2001, Jaring-Jaring Kehidupan, Yogyakarta: Penerbit Jalasutra.

Chambliss, William J. \& Siedman, Robert B., 1971, Law, Order, and Power, London: Addison-Wesley Publishing Company.

Griffiths, John, 2005,Memahami Pluralisme Hukum, Sebuah Deskripsi Konseptual, dalam Pluralisme Hukum, Sebuah Pendekatan Interdisiplin, Jakarta: HuMa.

Hardjasoemantri,Koesnadi, 2005, Hukum Tata Lingkungan, Yogyakarta: UGM Press.

Hidayat, Arief dan Samekto, FX. Adji, 2005,Kajian Kritis Penegakan Hukum Lingkungan di Era Otonomi Daerah, Semarang: Badan Penerbit Universitas Diponegoro.

Marlina dan Riza,Faisal, 2013, Aspek Hukum Peran Masyarakat dalam Mencegah Tindak Pidana Perikanan, Medan: PT. Softmedia.

Marwoto dkk, Heriyanto, 2013, Statistik Perikanan Tangkap 2012, Jakarta: Kementerian Kelautan dan Perikanan. 
Menski, Werner, 2006, Comparative Law in A Global Context (The Legal System of Asia and Africa), Second Edition, Cambridge University Press.

Nonet, Phililppe \& Selznick, Philip, 2008, Hukum Responsif, Penerjemah Raisul Muttaqin, Cetakan Ke-2, Bandung: Penerbit Nusa Media.

Nurjaya, I. Nyoman, 2008, Pengelolaan Sumberdaya Alam dalam Perspektif Antropologi Hukum, Jakarta: Prestasi Pustaka Publisher.

Poerwanti, Hari, 2008, Kebudayaan dan Lingkungan dalam Perspektif Antropologi, Yogyakarta: Penerbit Pustaka Pelajar.

Rahardjo, Satjipto, 2006, Ilmu Hukum, Cetakan Keenam, Bandung:PT. Citra Aditya Bakti.

2006, Hukum dalam Jagad Ketertiban, Jakarta: UKI Press.

2007,Mendudukkan UUD: Suatu Pembahasan dari Optik IImu Hukum Umum, Semarang: BP Undip.

Rato, Dominikus, 2009, Hukum dalam Perspektif Konstruksi Sosial, Jember, Fakultas Hukum Universitas Jember.

Ritzer, George \& Goodman, Douglas J., 2004, Teori Sosiologi Modern, (terjemahan Alimandan), Jakarta: Prenada Media Kencana.

Ronald Z. Titahelu, 2005, Pengakuan Hukum Formal Atas Pengelolaan Lokal Maupun Tradisional Atas Sumberdaya Pesisir sebagai Syarat untuk Meningkatkan Kepercayaan Diri Komunitas Pesisir dan Pulau-pulau Kecil, dalam Pluralisme Hukum, Sebuah Pendekatan Interdisiplin, Jakarta: HuMa.

Samekto, FX. Adji, 2008,Justice Not For All: Kritik terhadap Hukum Modern dalam Perspektif Studi Hukum Kritis, Yogyakarta: Genta Press.

2008, Kapitalisme, Modernisasi, dan Kerusakan Lingkungan, Yogyakarta: Genta Press.

Shidarta, "Posisi Pemikiran Teori Hukum Adat Mohammad Koesnoe dalam Konfigurasi Aliran Pemikiran Hukum (Sebuah Diagnosa Awal)", dalam Joeni Arianto Kurniawan (Ed.), 2013, Mohammad Koesnoe dalam Pengembangan Gagasan Hukum Indonesia, Jakarta: Epistema Institute dan HuMA.

Simarmata, Rikardo, 2005, Mencari Karakter Aksional dalam Pluralisme Hukum", dalam Pluralisme Hukum, Sebuah Pendekatan Interdisiplin, Jakarta: HuMa. 
Soemadiningrat, HR. Otje Salman, 2002, Rekonseptualisasi Hukum Adat Kontemporer, Bandung: Penerbit PT. Alumni.

Solihin, Akhmad, 2010, Politik Hukum Kelautan dan Perikanan, Isu, Permasalahan, dan Telaah Kritis Kebijakan, Bogor: Penerbit Nuansa Aulia.

Suteki, 2013, Desain Hukum di Ruang Sosial, Yogyakarta, Satjipto Rahardjo Institute dan Thafa Media.

Syaref, Sanusi M., 2002, Riwang U Laot, Leuen Pukat dan Panglima Laot dalam Kehidupan Nelayan di Aceh, Jakarta: Penerbit CSSP.

Tribawono, Djoko, 2013, Hukum Perikanan Indonesia, Cetakan Kedua, Bandung: Citra Adytia Bakti.

Usman, Sabian, 2013, Restoratif Justice Hukum Masyarakat Nelayan Saka dalam Sistem Hukum Nasional, Hukum Penguasaan, Pemilikan, dan Konflik Saka, Yogyakarta: Penerbit Pustaka Pelajar.

Usman, Sabian, 2011, Living Law, Transformasi Hukum Saka dalam Identitas Hukum Nasional, Yogyakarta: Penerbit Pustaka Pelajar.

Warassih, Esmi, 2005, Pranata Hukum, Sebuah Telaah Sosiologis, Semarang: Penerbit PT. Suryandaru Utama.

JURNAL

Firdaus, Muhammad, 2010, Hasil Tangkapan dan Laju Tangkap Unit Perikanan Pukat Tarik, Tugu, dan Kelong, Jurnal Makara Teknologi, Vol. 14, No. 1.

Nurjaya, I. Nyoman,2007, Pembangunan Hukum Negara dalam Masyarakat Multikultural, Perspektif Hukum Progresif, Jurnal Hukum Progresif, Vol. 3 No. 2.

Sulaiman, 2011, Kearifan Tradisional dalam Pengelolaan Sumberdaya Perikanan di Aceh Pada Era Otonomi Khusus, Jurnal Dinamika Hukum, Vol. 11, No. 2.

2009, Pelaksanaan Hukum Adat Laut dalam Pengelolaan Perikanan di Aceh, Jurnal Mondial, Vol. 11 No. 19. 


\section{DISERTASI}

Bernard L.Tanya, 2000, Beban Budaya Lokal Menghadapi Hukum Negara: Analisa Budaya atas Kesulitan Sosio Kultural Menghadapi Regulasi Negara, Semarang, Disertasi PDIH Undip.

Dominikus Rato, 2004, Hukum yang Berkenaan dengan Tanah dalam Kosmologi Masyarakat Osing, Semarang, Disertasi PDIH Undip.

Rini Fidiyani, 2009, Sengketa di Pasar Tradisional: Studi Antropologi Hukum tentang Penyelesaian Sengketa Jual Beli di Pasar Tradisional Banyumas, Semarang, Disertasi PDIH.

\section{MAKALAH}

Ari Purbayanto, Tinjauan Teknis Pengoperasian Trawl di Indonesia, Disampaikan dalam Panel Diskusi Analisa Kebijakan Pengoperasian Pukat Trawl, Diselenggarakan oleh Bappenas, Jakarta, Juni 2007.

Arief Hidayat, Negara Hukum Pancasila, Model Ideal Penyelenggaraan Negara Hukum", Disampaikan dalam Semiloka Pancasila dan Konstitusi, yang diselenggarakan Mahkamah Konstitusi, Jakarta, Agustus 2011.

Husni Mangga Barani, Kebijakan Pembangunan Perikanan Tangkap dan Pengelolaan Sumberdaya Udang serta Alat Tangkap Trawl, Disampaikan dalam Panel Diskusi Nasional Kebijakan Perikanan Tangkap. Yang diselenggarakan Departemen Kelautan dan Perikanan, Bogor, Tanggal 25 Oktober 2003.

\section{WEBSITE}

Djoko Tribawono, Pukat Hela antara Pro dan Kontra, http://www.kkp.go.id/index.php/arsip/c/983/PUKAT-HELA-ANTARA-PRODAN-KONTRA/, diunduh, 25 Oktober 2013, jam 10.15 Wib.

Sabar Subekti, Jaring Pukat Meninggalkan Penderitaan bagi Nelayan, http://satuharapan.com/index.php?id = 109\&tx ttnews[tt news]=3463\&cHas $\underline{h=1}$, diunduh 6 November 2013, pukul 14.40 Wib. 


\section{PERATURAN PERUNDANGAN}

UUD NRI 1945.

Undang-Undang Nomor 45 Tahun 2009 tentang Perubahan Undang-Undang Nomor 31 Tahun 2004.

Keputusan Presiden Nomor 39 Tahun 1980 tentang Larangan Trawl.

Keputusan Presiden Nomor 85 Tahun 1982 tentang Penggunaan Pukat Udang.

SK Menteri Pertanian No. 607/Kpts/Um/9/1976 tentang Jalur Penangkapan Ikan.

SK Menteri Pertanian Nomor 503/KPTS/UM/7/1980 tentang Jalur Penangkapan Ikan. 